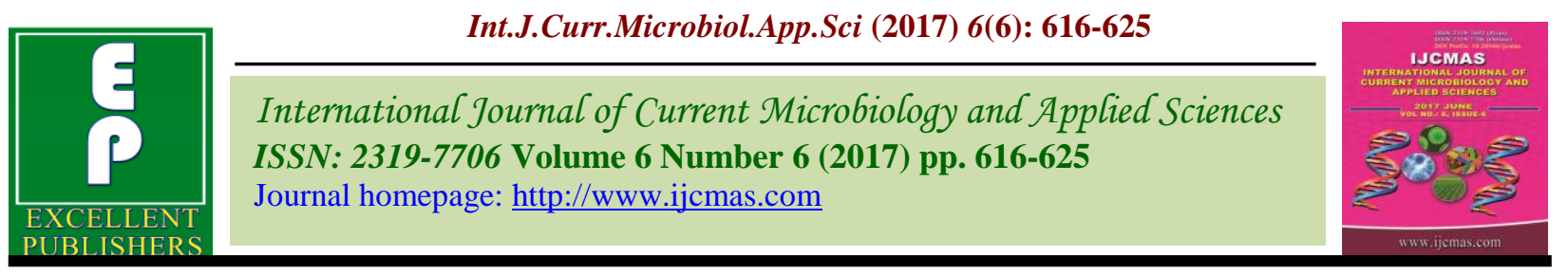

Original Research Article

https://doi.org/10.20546/ijcmas.2017.606.073

\title{
Temporal Changes in Prices of Sugar in India
}

\author{
Kavita", R.K. Grover, Raj Kumar and Sumit \\ ${ }^{1}$ Department of Agricultural Economics, CCSHAU, Hisar-125004, India \\ *Corresponding author
}

\begin{tabular}{|c|c|}
\hline & A B S T R A C T \\
\hline Keywords & $\begin{array}{l}\text { The present study was based on secondary data, collected from various } \\
\text { published and unpublished sources, i.e., Cooperative Sugar, Indian Sugar, }\end{array}$ \\
\hline $\begin{array}{l}\text { Sugar } \\
\text { production, } \\
\text { Growth, } \\
\text { Variations, } \\
\text { Trend. }\end{array}$ & $\begin{array}{l}\text { Statistical Abstract of India and Indian Agriculture in Brief and Agriculture } \\
\text { Prices in India. Data were collected for the periods } 1947-48 \text { to } 2013-14 \text {. The } \\
\text { coefficients of variation were } 30.22,35.39,42.53 \text { and } 105.89 \text { percent during } \\
\text { period I, II, III and IV, respectively, indicating that stability in the sugar prices } \\
\text { was maximum during period I. Linear growth rates were found to be 5.16, }\end{array}$ \\
\hline Article Info & $4.98,4.80$ and 4.71 percent during period III, I, IV and II, respectively. There \\
\hline $\begin{array}{l}\text { Accepted: } \\
\text { 04 May } 2017 \\
\text { Available Online: } \\
\text { 10 June } 2017\end{array}$ & $\begin{array}{l}\text { check fall in sugar price and to protect the domestic growers. The export } \\
\text { should be restricted and import should be encouraged to stabilize domestic } \\
\text { price of sugar. }\end{array}$ \\
\hline
\end{tabular}

\section{Introduction}

Sugar production in India has been cyclic in nature. As estimated about 75 percent of the population directly or indirectly depends on sugar sector. Sugar industry has also expected to develop further, thereby offering more employment opportunities to a number of semi-skilled and skilled workers in rural areas of the country and contributing towards their development. The sugar industry also supports diversified ancillary activities and skills that support the local economy. The dependent population creates substantial demand for local goods and services. Production of sugar depends on recovery rate of mills that mainly depends on sucrose content in sugarcane, conditions of plant and machinery, cane supply arrangement in the state and agro-climatic conditions in the region (CACP Report, 2011). In India, the recovery rate has been hovering around 10 percent for a long time despite the fact that the government has extended large assistance from Sugar Development Fund (SDF) to cane development for modernization of plant and machinery of sugar mills.

Indian sugar production is characterized by a cyclic production pattern with typical sugar cycles lasting 2-3 years, as the production adjusts to fall in price, which in turn leads to lower supplies, price increase and higher production. The growing Indian economy and a growing population (about 1.8 percent per annum) would support growth in sugar 
consumption. Bulk consumers such as soft drink manufacturers, bakery, confectionary, hotel and restaurant consumers account for 60 percent of milled sugar demand. Local sweet shops consume most of India's khandsari sugar production. Gur is mostly consumed in rural areas for household consumption and feed use (USDA, 2012). In India, like many other countries in the world, stabilization of sugar price is an important element of food policy. Since output continues to depend largely on uncertain monsoons, domestic price stabilization remains a key objective of the government's food grain policies. Keeping the above facts in view, an attempt was made to analyze growth and variations of sugar price in India.

\section{Materials and Methods}

The present study was based on secondary data of sugar price collected from various published and unpublished sources, i.e. Cooperative Sugar, Indian Sugar, Statistical Abstract of India, Indian Agriculture in Brief and Agriculture Prices in India for the period from 1947-48 to 2013-14. The data were grouped into four periods depending upon the extent of government intervention in terms of control, decontrol, or partial control through various levels of levy on sugar. Period I is characterized by full decontrol of government on sugar and ranged from 1947-48 to 196667 , period II from 1967-68 to 1987-88 which was the period of partial control, and the extent of levy sugar was 50 percent or more, period III from 1988-89 to 2011-12 and again was the period of partial control, when levy sugar was less than 50 percent and period IV denotes overall period of study ranging from 1947-48 to 2013-14.

To determine the trends in sugar price, linear growth rates was calculated by fitting following equation using price data for all the four periods:
$\mathrm{Y}=\mathrm{a}+\mathrm{bt}$

Where,

$\mathrm{Y}=$ Sugar price

$\mathrm{a}=$ Intercept

$\mathrm{b}=$ Regression coefficient

$\mathrm{t}=$ Time variable in years

Linear growth rates were calculated with the help of following formula:

$\mathrm{LGR}=\frac{\mathrm{b}}{\text { Mean }} \times 100$

Where,

LGR $=$ Linear growth rate

$\mathrm{b}=$ Regression coefficient

Coefficient of variation was calculated with the help of the following formulae:

C. $V .=\frac{\text { S.D }}{\text { Mean }} \times 100$

Where,

C.V. = Coefficient of variation

S.D $=$ Standard deviation

\section{Results and Discussion}

Analysis of past trend is very much necessary for making plans to stabilize the price of sugar. With this intention, the growth rates in sugar price were estimated using time series for four periods covering 67 years. Sugar price has increased from ₹ 50.67/q in base year to ₹ $147.51 / \mathrm{q}$ in the year 1966-67. The linear growth rate found to the extent of 4.98 per cent per annum during this period. The coefficient of variation during the study period was found to be 30.22 per cent indicating the stability in sugar price in the period I and the trend in sugar prices in India for the above period is depicted in figure 1, which shows an increasing pattern (Table 1). 
Table 2 indicated that significant increase in sugar price, which varied from ₹ $181.66 / \mathrm{q}$ in year 1969-70 to ₹ 695.79/q in year 1980-81, whereas in the year 1979-80, the increment were witnessed in sugar price more than doubled as compared to the year 1978-79. Period-II showed the linear growth rate of sugar price was 4.71 per cent per annum. The coefficient of variation calculated to be 35.39 per cent indicating stability of sugar price during this period. Increasing trend in sugar prices during the above period is depicted in figure 2. Sugar prices increased over the period except few years, in which, there was decline trend in prices. The years, in which prices were decline 1969-70, 1977-78, 197879, 1981-82, and 1982-83 where the sugar prices declined by $98.29,85.09,84.18,161.46$ and 80.63 ₹/q, respectively from the previous year. The maximum decline in sugar price was observed during the year 1981-82 from the prices of previous year.

Table.1 Trend in sugar price in India for period I (1947-48 to 1966-67)

\begin{tabular}{|c|c|c|}
\hline Year & Price (₹ /q) & Estimated Value \\
\hline $1947-48$ & 50.67 & 47.93 \\
\hline $1948-49$ & 55.45 & 52.48 \\
\hline $1949-50$ & 58.21 & 57.03 \\
\hline $1950-51$ & 60.66 & 61.58 \\
\hline $1951-52$ & 72.56 & 66.13 \\
\hline $1952-53$ & 75.00 & 70.68 \\
\hline $1953-54$ & 78.02 & 75.23 \\
\hline $1954-55$ & 80.04 & 79.78 \\
\hline $1955-56$ & 81.44 & 84.33 \\
\hline $1956-57$ & 84.28 & 88.88 \\
\hline $1957-58$ & 84.28 & 93.43 \\
\hline $1958-59$ & 92.63 & 97.98 \\
\hline $1959-60$ & 100.57 & 102.53 \\
\hline $1960-61$ & 101.40 & 107.08 \\
\hline $1961-62$ & 102.41 & 111.63 \\
\hline $1962-63$ & 109.33 & 116.18 \\
\hline 1963-64 & 124.37 & 120.73 \\
\hline $1964-65$ & 129.65 & 125.28 \\
\hline $1965-66$ & 135.98 & 129.83 \\
\hline $1966-67$ & 147.51 & 134.38 \\
\hline $\mathrm{a}$ & \multicolumn{2}{|l|}{43.38} \\
\hline $\mathrm{b}$ & \multicolumn{2}{|l|}{$4.55^{* *}$} \\
\hline SE & \multicolumn{2}{|l|}{0.23} \\
\hline $\mathrm{R}^{2}$ & \multicolumn{2}{|l|}{0.95} \\
\hline LGR (\%) & \multicolumn{2}{|l|}{4.98} \\
\hline $\mathrm{CV}(\%)$ & \multicolumn{2}{|l|}{30.22} \\
\hline
\end{tabular}

**Significant at 5 percent level of probability Source: Co-operative sugar 
Table.2 Trend in sugar price in India for period II

\begin{tabular}{|l|l|l|}
\hline Years & Prices(₹ /q) & Estimated Value \\
\hline $1967-68$ & 269.38 & 227.34 \\
\hline $1968-69$ & 279.95 & 247.59 \\
\hline $1969-70$ & 181.66 & 267.84 \\
\hline $1970-71$ & 183.95 & 288.09 \\
\hline $1971-72$ & 284.56 & 308.34 \\
\hline $1972-73$ & 357.14 & 328.59 \\
\hline $1973-74$ & 415.87 & 348.84 \\
\hline $1974-75$ & 462.06 & 369.09 \\
\hline $1975-76$ & 449.37 & 389.34 \\
\hline $1976-77$ & 420.83 & 409.59 \\
\hline $1977-78$ & 335.74 & 429.84 \\
\hline $1978-79$ & 251.56 & 450.09 \\
\hline $1979-80$ & 547.79 & 470.34 \\
\hline $1980-81$ & 695.79 & 490.59 \\
\hline $1981-82$ & 534.33 & 510.84 \\
\hline $1982-83$ & 453.70 & 531.09 \\
\hline $1983-84$ & 483.62 & 551.34 \\
\hline $1984-85$ & 571.35 & 571.59 \\
\hline $1985-86$ & 604.70 & 591.84 \\
\hline $1986-87$ & 604.25 & 612.09 \\
\hline $1987-88$ & 639.27 & 632.34 \\
\hline $\mathrm{a}$ & 207.09 & \\
\hline $\mathrm{b}$ & $20.25 * *$ & \\
\hline $\mathrm{R}^{2}$ & 0.68 & \\
\hline SE & 3.17 & \\
\hline LGR $(\%)$ & 4.71 & \\
\hline CV $(\%)$ & 35.39 & \\
\hline
\end{tabular}

**Significant at 5\% level of probability Source: Co-operative sugar 
Table.3 Trend in the sugar price in India for period III

\begin{tabular}{|c|c|c|}
\hline Years & $\operatorname{Prices}(₹ / \mathbf{q})$ & Estimated Value \\
\hline 1988-89 & 755.39 & 639.07 \\
\hline $1989-90$ & 826.17 & 720.22 \\
\hline 1990-91 & 854.66 & 801.37 \\
\hline $1991-92$ & 882.79 & 882.52 \\
\hline $1992-93$ & 1024.87 & 963.67 \\
\hline 1993-94 & 1323.27 & 1044.82 \\
\hline 1994-95 & 1234.53 & 1125.97 \\
\hline $1995-96$ & 1316.56 & 1207.12 \\
\hline 1996-97 & 1359.56 & 1288.27 \\
\hline $1997-98$ & 1482.41 & 1369.42 \\
\hline 1998-99 & 1430.62 & 1450.57 \\
\hline 1999-00 & 1467.77 & 1531.72 \\
\hline $2000-01$ & 1446.97 & 1612.87 \\
\hline $2001-02$ & 1376.78 & 1694.02 \\
\hline $2002-03$ & 1332.98 & 1775.17 \\
\hline $2003-04$ & 1485.17 & 1856.32 \\
\hline $2004-05$ & 1759.81 & \begin{tabular}{|l|}
1937.47 \\
\end{tabular} \\
\hline 2005-06 & 1888.87 & 2018.62 \\
\hline $2006-07$ & 1508.75 & 2099.77 \\
\hline 2007-08 & 1542.83 & 2180.92 \\
\hline 2008-09 & 2230.80 & 2262.07 \\
\hline $2009-10$ & 3129.29 & 2343.22 \\
\hline $2010-11$ & 2898.38 & 2424.37 \\
\hline 2011-12 & 3176.33 & 2505.52 \\
\hline $\mathrm{a}$ & \multicolumn{2}{|l|}{557.92} \\
\hline $\mathrm{b}$ & \multicolumn{2}{|l|}{$81.15^{* *}$} \\
\hline $\mathrm{SE}$ & \multicolumn{2}{|l|}{10.36} \\
\hline $\mathrm{R}^{2}$ & \multicolumn{2}{|l|}{0.73} \\
\hline LGR (\%) & \multicolumn{2}{|l|}{5.16} \\
\hline $\mathrm{CV}(\%)$ & \multicolumn{2}{|l|}{42.53} \\
\hline
\end{tabular}

**Significant at 5 percent level of probability Source: Co-operative sugar 
Table.4 Trend in the sugar price in India for period IV

\begin{tabular}{|l|l|l|}
\hline Years & Prices(₹ /q) & Estimated Value \\
\hline $1947-48$ & 50.67 & -480.73 \\
\hline $1948-49$ & 55.45 & -441.24 \\
\hline $1949-50$ & 58.21 & -401.75 \\
\hline $1950-51$ & 60.66 & -362.26 \\
\hline $1951-52$ & 72.56 & -322.77 \\
\hline $1952-53$ & 75.00 & -283.28 \\
\hline $1953-54$ & 78.02 & -243.79 \\
\hline $1954-55$ & 80.04 & -204.3 \\
\hline $1955-56$ & 81.44 & -164.81 \\
\hline $1956-57$ & 84.28 & -125.32 \\
\hline $1957-58$ & 84.28 & -85.83 \\
\hline $1958-59$ & 92.63 & -46.34 \\
\hline $1959-60$ & 100.57 & -6.85 \\
\hline $1960-61$ & 101.40 & 32.64 \\
\hline $1961-62$ & 102.41 & 72.13 \\
\hline $1962-63$ & 109.33 & 111.62 \\
\hline $1963-64$ & 124.37 & 151.11 \\
\hline $1964-65$ & 129.65 & 190.6 \\
\hline $1965-66$ & 135.98 & 230.09 \\
\hline $1966-67$ & 147.51 & 269.58 \\
\hline $1967-68$ & 269.38 & 309.07 \\
\hline $1968-69$ & 279.95 & 348.56 \\
\hline $1969-70$ & 181.66 & 388.05 \\
\hline $1970-71$ & 183.95 & 427.54 \\
\hline $1971-72$ & 284.56 & 467.03 \\
\hline $1972-73$ & 357.14 & 506.52 \\
\hline $1973-74$ & 415.87 & 546.01 \\
\hline $1974-75$ & 462.06 & 585.5 \\
\hline $1975-76$ & 449.37 & 624.99 \\
\hline $1976-77$ & 420.83 & 664.48 \\
\hline $1977-78$ & 335.74 & 703.97 \\
\hline $1978-79$ & 251.56 & 743.46 \\
\hline $1979-80$ & 547.79 & 782.95 \\
\hline $1980-81$ & 695.79 & 822.44 \\
\hline $1981-82$ & 534.33 & 861.93 \\
\hline $1982-83$ & 453.70 & 901.42 \\
\hline $1983-84$ & 483.62 & 940.91 \\
\hline $1984-85$ & 571.35 & 980.4 \\
\hline $1985-86$ & 604.70 & 1019.89 \\
\hline $1986-87$ & 604.25 & 1059.38 \\
\hline $1987-88$ & 639.27 & 1098.87 \\
\hline $1988-89$ & 755.39 & 1138.36 \\
\hline $1989-90$ & 826.17 & 117.85 \\
\hline $1990-91$ & & \\
\hline & 854.66 & \\
\hline & & \\
\hline & & \\
\hline & & \\
\hline 196.34 \\
\hline
\end{tabular}




\begin{tabular}{|l|l|l|}
\hline $1991-92$ & 882.79 & 1256.83 \\
\hline $1992-93$ & 1024.87 & 1296.32 \\
\hline $1993-94$ & 1323.27 & 1335.81 \\
\hline $1994-95$ & 1234.53 & 1375.3 \\
\hline $1995-96$ & 1316.56 & 1414.79 \\
\hline $1996-97$ & 1359.56 & 1454.28 \\
\hline $1997-98$ & 1482.41 & 1493.77 \\
\hline $1998-99$ & 1430.62 & 1533.26 \\
\hline $1999-00$ & 1467.77 & 1572.75 \\
\hline $2000-01$ & 1446.97 & 1612.24 \\
\hline $2001-02$ & 1376.78 & 1651.73 \\
\hline $2002-03$ & 1332.98 & 1691.22 \\
\hline $2003-04$ & 1485.17 & 1730.71 \\
\hline $2004-05$ & 1759.81 & 1770.2 \\
\hline $2005-06$ & 1888.87 & 1809.69 \\
\hline $2006-07$ & 1508.75 & 1849.18 \\
\hline $2007-08$ & 1542.83 & 1888.67 \\
\hline $2008-09$ & 2230.80 & 1928.16 \\
\hline $2009-10$ & 3129.29 & 1967.65 \\
\hline $2010-11$ & 2898.38 & 2007.14 \\
\hline $2011-12$ & 3176.33 & 2046.63 \\
\hline $2012-13$ & 3310.91 & 2086.12 \\
\hline $2013-14$ & 3204.44 & 2125.61 \\
\hline a & -520.22 & \\
\hline$b$ & $39.49 * *$ & \\
\hline SE & 2.59 & \\
\hline $\mathrm{R}^{2}$ & 0.78 & \\
\hline LGR $(\%)$ & 4.80 & \\
\hline CV $(\%)$ & 105.89 & \\
\hline
\end{tabular}

**Significant at 5 percent level of probability Source: Co-operative sugar

Table.5 Comparative analysis of coefficients of variation and linear growth rates of sugar price in India over the selected periods

\begin{tabular}{|l|c|c|}
\hline Period & Coefficient of Variation (\%) & Linear growth rate (\%) \\
\hline Period-I & 30.22 & 4.98 \\
\hline Period-II & 35.39 & 4.71 \\
\hline Period-III & 42.53 & 5.16 \\
\hline Period-IV & 105.89 & 4.80 \\
\hline
\end{tabular}


Fig.1 Trend in sugar price in India for period I

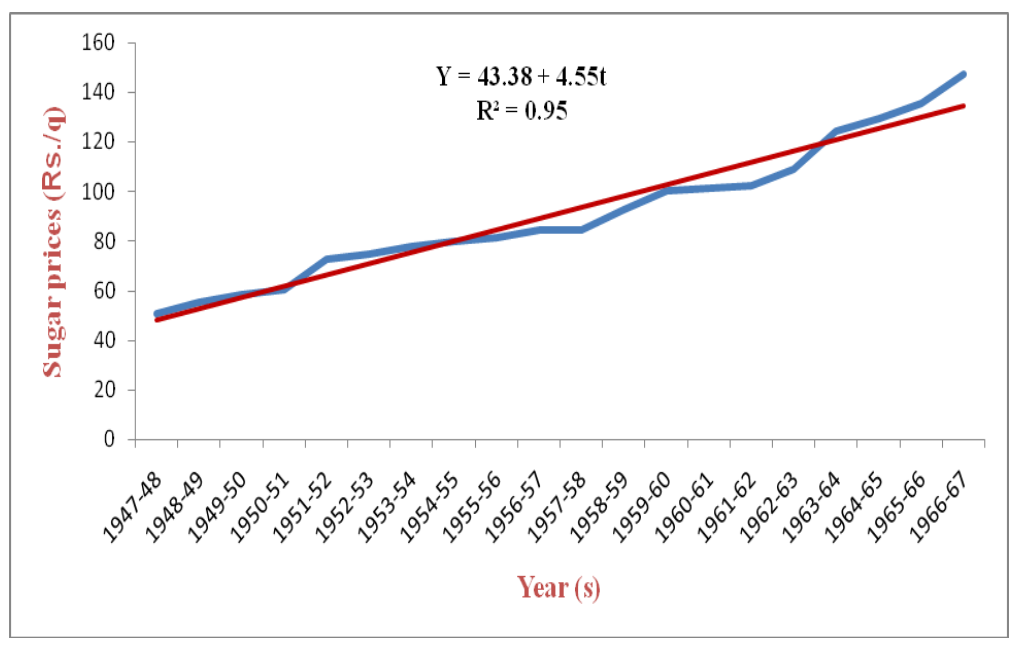

Fig.2 Trend in sugar price in India for period II

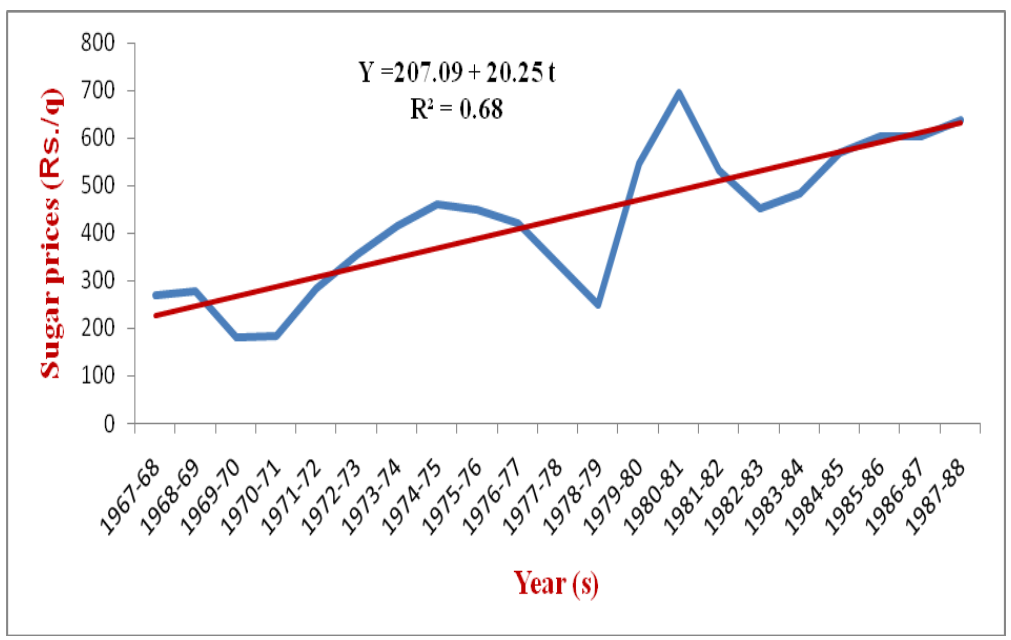

Fig.3 Trend in sugar price in India for period III

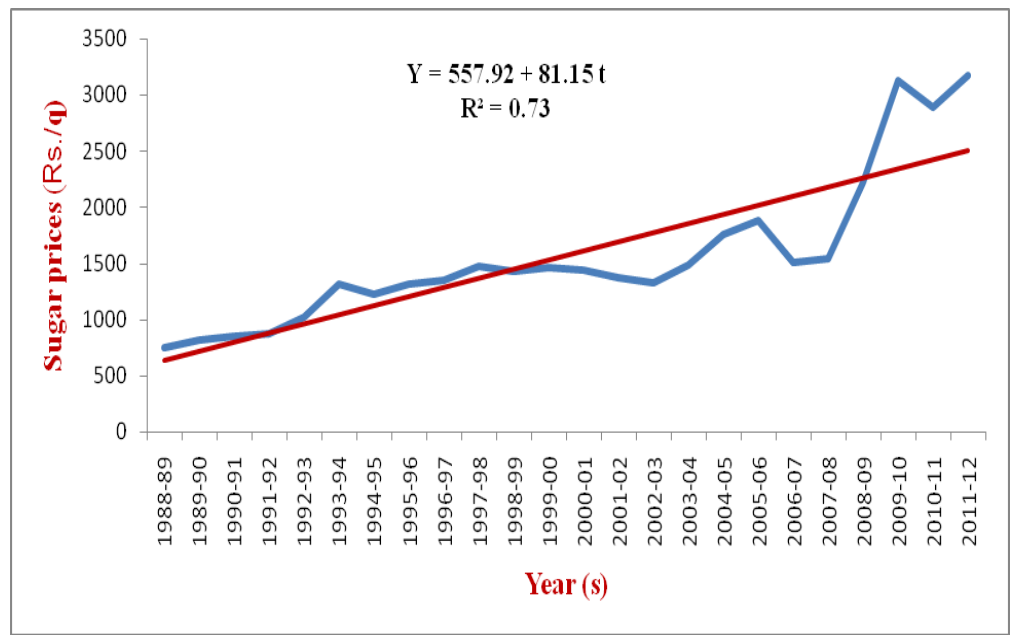


Fig.4 Trend in sugar price in India for period IV

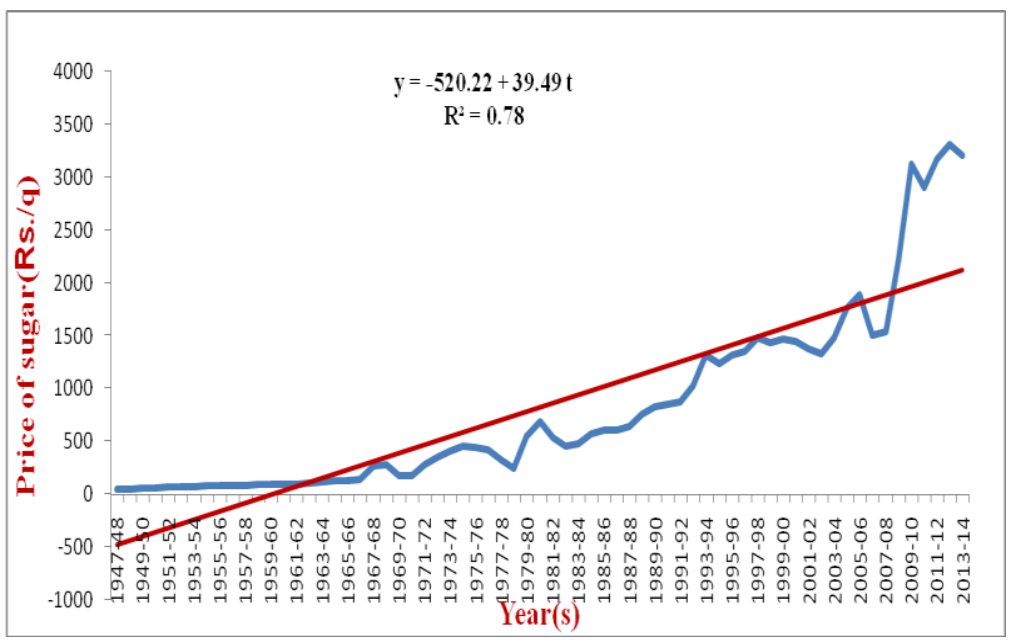

In period III, there had been a positive and significant increase in sugar prices over the years as manifested from the linear growth of 5.16 per cent per annum. The sugar price varied from 755.39 ₹ /q in base year of the period III to $3176.33 ₹ / \mathrm{q}$ in end year of period, similarly coefficient of variation calculated to be 42.53 per cent, which reflect the fluctuation in sugar prices during the same period (Table 3 and Figure 3).

The trend in sugar prices in India from 194748 to 2013-14 is elucidated in table 4. Sugar prices were ranged between $50.67 ₹ / \mathrm{q}$ to 3204.44 ₹/q in year 2013-14. During the period IV sugar prices showed significantly increasing trend with the growth rate $4.80 \%$ per annum. As shown in figure 4 , there was a growing tendency except for the first three years, 1969-70, 1977-78, and 1978-79. After that, there was a slight increase in the beginning of the year 2005-06 and by the end of the year till the end of the year and then from 2006-07 to the year 2013-14 sugar prices suddenly increased, when in 2010-11 the price was $231.91 ₹$ / Was reduced every year.

The value of coefficient of determination indicated the percent of variation in sugar price (dependable variable) caused due to time period (independent variable). The R2 value was found 0.78 over the whole period of study.

The data presented in table 5 indicated that the coefficients of variation were 30.22 , $35.39,42.53$, and 105.89 percent during the period I, II, III and IV, respectively; indicating that stability in sugar prices was maximum during period I as compared to other periods. The linear growth rates were calculated to be 5.16, 4.98, 4.80 and 4.71 during the period III, I, IV and II respectively.

In conclusion, the trend in sugar prices indicated that there was a significant increase in sugar prices over all the periods. The Control of sugar trade had a tendency to increase the price of sugar, with stability in prices whereas, decontrol led to a tendency in falling of sugar price with the instability in sugar prices. The analysis of data indicates that under the period III (partial control levy less than 50 percent), there was a declining tendency in sugar prices, however, the instability in sugar price was relatively higher than period I and the period of partial control had a levy more than 50 per cent. 
To stabilize the sugar price, there is a need to increase the area and production of sugarcane on sustainable basis. The cost of sugar production can be decreased by evolving sugarcane varieties with more sugar content, and resistance against insect-pests and diseases. Government should intervene proper and timely, depending upon the prevailing stocks, demand and supply, international and domestic sugar price.

\section{References}

CACP (2011). http://cacp.dacnet.nic.in/View Reports.aspx ?Input $=2 \&$ Page Id $=41 \& \mathrm{Ke}$ $\mathrm{yId}=421$.

Elobeid, A. (2009). How would a Trade Deal on Sugar Affect Exporting and Importing Countries International Centre for Trade and Sustainable
Development? (ICTSD), Issue Paper No. 24.

Mittal and Reimer (2007). Would Indian farmers benefit from liberalization of world cotton and sugar markets? Agricultural Economics, 38: 301-312.

Panchamukhi, V.R. (1986). Trade in Agricultural Commodities: A Profile of Two Decades (1960-80).

Singh, V. and Kumar, V. (1999). Trends, challenges and the outlook of world cane and sugar production market. In: Proceedings of the 23rd ISSCT Congress, New Delhi, India,

Sommer, V. (2004). The market for sugar. Agrarwirtschaft, 53(1): 18-23.

USDA (2012) India: Sugar annual 2012", Global agriculture information network report no: IN 2058, Foreign Agriculture service, United States, Department of agriculture (USDA).

\section{How to cite this article:}

Kavita, R.K. Grover, Raj Kumar and Sumit. 2017. Temporal Changes in Prices of Sugar in India. Int.J.Curr.Microbiol.App.Sci. 6(6): 616-625.

doi: https://doi.org/10.20546/ijcmas.2017.606.073 